\title{
Effects of Fungal Lytic Enzymes and Non-ionic Detergents on the Actions of Some Fungicides against Pyricularia oryzae
}

\author{
Reiko Watanabe, * Nagahiro OGasawara, Hirosato Tanaka \\ and Takeo UCHIYAMA \\ Department of Agricultural Chemistry, Faculty of Agriculture, \\ Niigata University, Niigata 950-21, Japan \\ * Niigata Women's College, Niigata 950, Japan
}

Received June 25, 1987

\begin{abstract}
The combined use of a tytic enzyme complex of Bacillis circulans WL 12 and a detergent, Emulgen 120 , caused effective reduction of the minimal inhibitory concentrations of the fungicides, Polyoxin B and Kitazin P, for Pyricularia oryzae. For Glomerella cingulata and Alternaria kikuchiana, the further addition of Novozym 234 or the crude enzyme from Streptomyces sp. was necessary for the same effect.
\end{abstract}

Bacillus circulans WL 12 produces a potent fungal lytic enzyme complex containing $\beta$-1,3and $\beta$-1,6-glucanases and chitinase. ${ }^{1)}$ We explored the possibility of reducing the minimal inhibitory concentrations (MIC) of some fungicides through the use of this lytic enzyme complex. In order to enhance the action of the lytic enzyme complex against fungi and to promote the cell permeation of the fungicides, the effects of the simultaneous addition of nonionic detergents were examined, because most non-ionic detergents have a negligible influence on the biological integrity of cells. ${ }^{2)}$

The simultaneous addition of the lytic enzyme complex, Emulgen 120 and Polyoxin B or Kitazin $P$ resulted in enhancement of the fungicidal actions of these agents against Pyricularia oryzae, Botrytis cinerea and Collectotrichum lagenarium. However, the further addition of mannanase and protease was necessary to induce similar effects for Glomerella cingulata and Alternaria kikuchiana. Chemical and topological differences of the cell surfaces of the fungi are considered to be responsible for this difference. The results may indicate a new screening method of fungicides.

\section{MATERIALS AND METHODS}

Organisms. Pyricularia oryzae $\mathrm{P}_{2}{ }^{11}$ and Glomerella cingulata $\mathrm{G} 4-1-4^{3)}$ were used. Botrytis cinerea, Colletotrichum lagenalium and Alternaria kikuchiana Y-33 (Polyoxins tolerant strain) were supplied by Kumiai Chemical Industry Co., Ltd. Tokyo. Bacillus circulans WL $12^{4}$, was used for the production of the lytic enzyme complex.

Detergents. The non-ionic detergents used were Emulgen 108 and Emulgen 120 (polyoxyethylene laurylether), Emulgen 909 (polyoxyethylene nonylphenolether), Tween 21 (polyoxyethylene sorbitane monolaulate), Tween 81 (polyoxyethylene sorbitane monooleate) and Pelex OTP (dioctylsulfo succinate).

Fungicides. Kasugamycin $\mathrm{HCl}$ was obtained from Hokko Chemical Industry Co., Ltd. Polyoxin B was obtained from Kaken Chemical Co., Ltd. Griseofulvin and Trichomycin were supplied by Nippon Kayaku Co., Ltd. and Fujisawa Yakuhin Kogyo Co., Ltd., respectively. Synthetic fungicides, Kitazin P (IBP, $S$-benzyl diisopropyl phosphorothiolate) and Vegita (ETM, ethylene thiuram monosulfide), were supplied by Kumiai Chemical Industry Co., Ltd. Kitazin $\mathbf{P}$ was dissolved in a minimal amount of dimethyl formamide and then diluted with distilled water.

Enzymes. The preparation of the lytic enzyme complex of $B$. circulans WL 12 was conducted according to Tanaka et al. ${ }^{5)}$ Beta-1,3-and $\beta$-1,6-glucanase and chitinase activities were assayed as described by Tanaka $e t$ al. ${ }^{1)}$ Cell wall lytic activity toward $P$. oryzae cell walls was determined as described by Kobayashi et al ${ }^{6)}$ The lytic enzyme complex 
Table I. Assay System for Determination of the MiCs of Fungicides

The details of the reaction mixture are given under MAterials and MEthods.

\begin{tabular}{lccccccc}
\hline Reaction mixture & $\mathrm{C}$ & $\mathrm{C}+\mathrm{E}$ & $\mathrm{C}+\mathrm{D}$ & $\mathrm{C}+\mathrm{F}$ & $\mathrm{C}+\mathrm{E}+\mathrm{D}$ & $\mathrm{C}+\mathrm{D}+\mathrm{F}$ & $\mathrm{C}+\mathrm{E}+\mathrm{D}+\mathrm{F}$ \\
\hline & & & & & & & $(\mathrm{ml})$ \\
Culture medium & 2.0 & 2.0 & 2.0 & 2.0 & 2.0 & 2.0 & 2.0 \\
Distilled water & 2.0 & 1.0 & 1.5 & 1.5 & 0.5 & 1.0 & - \\
Enzyme solution (E) & - & 1.0 & - & - & 1.0 & - & 1.0 \\
Fungicidal solution (F) & - & - & - & 0.5 & - & 0.5 & 0.5 \\
Detergent solution (D) & - & - & 0.5 & - & 0.5 & 0.5 & 0.5 \\
Mycelial suspension & 1.0 & 1.0 & 1.0 & 1.0 & 1.0 & 1.0 & 1.0 \\
\hline \multicolumn{1}{c}{ Total } & 5.0 & 5.0 & 5.0 & 5.0 & 5.0 & 5.0 & 5.0 \\
\hline
\end{tabular}

used in this study contained $\beta$-1,3-glucanase (200 units/ $\mathrm{ml})$ and chitinase $(10$ units $/ \mathrm{ml})$. The reaction mixtures contained 50 units $/ \mathrm{ml}$ of cell wall lytic activity. Novozym 234, purchased from Novo Industry Japan Ltd, was used at a final concentration of $0.8 \mathrm{mg} / \mathrm{ml}$ in the reaction mixtures.

Assay system for determination of the MICs of fungicides. The minimal inhibitory concentration of a fungicide for a certain fungus is defined as the minimal concentration of the fungicide that causes complete growth arrest.

$P$. oryzae was grown at $28^{\circ} \mathrm{C}$ for 10 to 14 days on Misato's medium agar slants. " The conidial suspension obtained from a slant was poured into $100 \mathrm{ml}$ of Vogel- $N$ sucrose-yeast extract medium ${ }^{1)}$ in a $500 \mathrm{ml}$ Sakaguchi flask. After a shaking culture at $28^{\circ} \mathrm{C}$ for $24 \mathrm{hr}$, the mycelium, collected by centrifugation at $1,500 \times g$ for $10 \mathrm{~min}$ and washed twice with $1 / 15 \mathrm{~m}$ phosphate buffer $(\mathrm{pH}$ 6.5 ), suspended in $25 \mathrm{ml}$ of the same buffer. Mycelial suspensions of $G$. cingulata, $B$. cinerea and $C$. lagenarium were made in the same manner except for the conidiation medium (potato-sucrose agar). For A. kikuchiana, the mycelial suspension was prepared from a culture grown on a modified potato-sucrose agar. Table I shows the assay systems. The culture medium $(2 \%$ sucrose potato extract solution), detergent solution and distilled water were dispensed into L-shaped test tubes and autoclaved. The fungicide and enzyme solution were aseptically filtered through a Millipore filter (GSWP for an aqueous solution, FGLP for an organic solvent solution), and then pipetted into the L-shaped test tubes. Finally, $1.0 \mathrm{ml}$ of a mycelial suspension (about $2.5 \mathrm{mg}$ in dry weight) was added to the tubes. These reaction mixtures were incubated on a gentle shaking device (Taiyo, thermo unit, Tokyo) at $28^{\circ} \mathrm{C}$ for 5 days and observed with the naked eye at constant intervals, and the mycelial dry weights were measured.

The mycelial dry weight in each reaction mixture was measured as follows. The mycelium was harvested on a Millipore filter (HAWP), and then the mycelium together with the filter was dried at $80^{\circ} \mathrm{C}$ for $60 \mathrm{~min}$, kept in a desiccator for $30 \mathrm{~min}$ and weighed, and finally the filter weight was subtracted.

Estimation of mycelial damage. After incubation at $28^{\circ} \mathrm{C}$ for $48 \mathrm{hr}$, a reaction mixture $(5.0 \mathrm{ml})$ was filtered through a Millipore filter. The filtrate was diluted 5-fold with distilled water, and then the absorbance at $260 \mathrm{~nm}$ was measured with a Hitachi 124 spectrophotometer (Tokyo) to estimate the extent of mycelial damage. The results were expressed as optical densities.

Electron microscopy. The methods used were the same as described previously. ${ }^{3)}$

\section{RESULTS}

Action of the lytic enzyme complex on the growth of $P$. oryzae

The enzymes produced by $B$. circulans WL 12 degraded the cell wall of living mycelium. After incubation at $28^{\circ} \mathrm{C}$ for $3 \mathrm{hr}$, the mycelium was completely fragmented and could not be observed with the naked eye. A electron micrograph of the fragmented mycelium is shown in Fig. 1. However, the fragmented mycelium grew again in the same reaction mixture $(\mathrm{C}+\mathrm{E}$ in Table $\mathrm{I})$, and the mycelial dry weight had increased to $14.3 \mathrm{mg}$ after incubation for $48 \mathrm{hr}$. On the other hand, the mycelial dry weight in the basal medium $(\mathrm{C}$ in Table I) without the enzyme complex reached only $12.2 \mathrm{mg}$ in the same growth period. Similar results were obtained even when the lytic enzyme complex with higher activities was used. The activation of glucan and chitin 

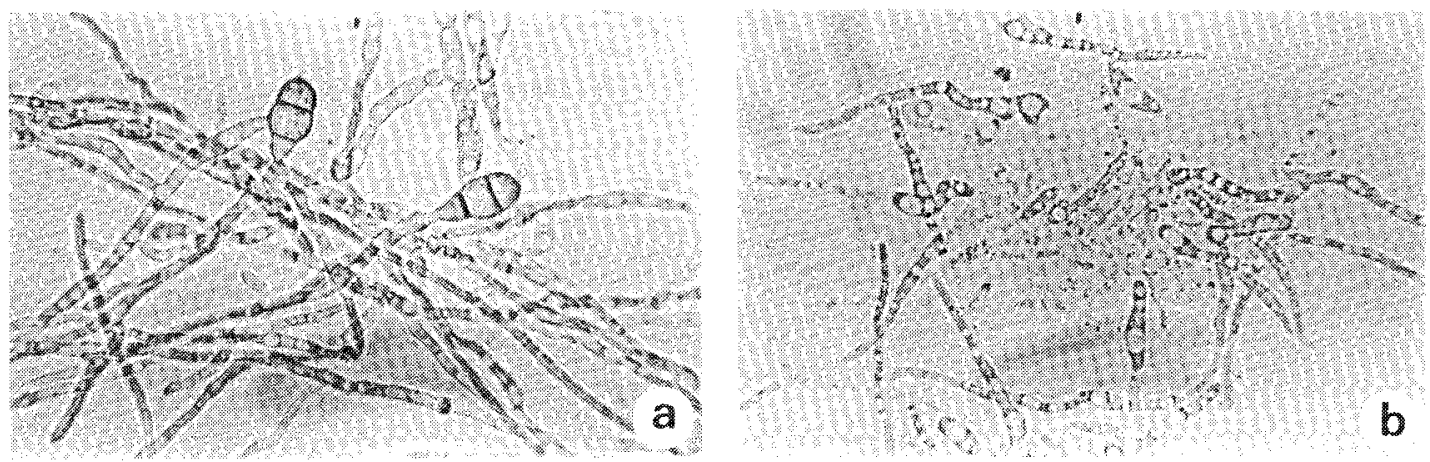

FIG. 1. P. oryzae Treated with the Lytic Enzyme Complex from B. circulans WL 12.

a: Control mycelium without the lytic enzyme complex.

b: Fragmented mycelium after incubation at $28^{\circ} \mathrm{C}$ for $3 \mathrm{hr}$

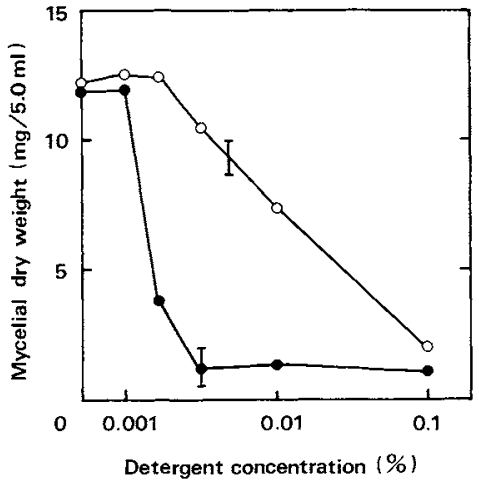

FIG. 2. Effects of Detergents on the Growth of $P$. oryzae.

Mixtures containing the mycelium $(2.5 \mathrm{mg})$ and different amounts of the detergents $(\mathrm{C}+\mathrm{D}$, see Table $\mathrm{I})$, Emulgen $120(\mathrm{O})$ or Emulgen 909 (O), were incubated at $28^{\circ} \mathrm{C}$ for $48 \mathrm{hr}$ in a total volume of $5 \mathrm{ml}$. The symbol, $\mathrm{K}$, indicates CMC of the detergent.

synthase zymogens due to extensive mycelial damage and/or formation of many hyphal apexes might be responsible for this phenomenon.

Effects of detergents on the growth of P. oryzae

Figure 2 shows the relationship between the growth of $P$. oryzae and the concentration of a non-ionic detergent after incubation at $28^{\circ} \mathrm{C}$ for $48 \mathrm{hr}$. The critical micelle concentration (CMC) of a detergent is defined as the concentration at which some properties of the solution, such as osmotic pressure, change abruptly. With one group of which Emulgen
$120(\mathrm{CMC}=0.007 \%)$ is a typical example, mycelial growth was slightly influenced at concentrations above $0.01 \%$ and the growthinhibition was essentially not affected by CMC. Tween $21(0.015 \%)$, Tween $81(0.008 \%)$ and Pelex OTP $(0.029 \%)$ belong to this group. In the other group of which Emulgen 909 $(0.005 \%)$ is typical, the growth-inhibiting action was seen at lower concentrations and the mycelial growth was inhibited remarkably beyond CMC. Emulgen $108(0.004 \%)$ showed a similar effect.

Effects of the lytic enzyme complex and Emulgen 120 on the inhibitory actions of fungicides on the growth of P. oryzae

Emulgen 120 was selected on the basis of the results of the preliminary combination test on the lytic enzyme complex and detergents with $P$. oryzae. From the MICs of eleven fungicides against $P$. oryzae, we selected six fungicides; Kasugamycin $\mathrm{HCl}$, Polyoxin B, Griseofulvin, Trichomycin, Kitazin $\mathrm{P}$ and Vegita. The synergistic action of one of these fungicides, the lytic enzyme complex and Emulgen 120 on the growing $P$. oryzae mycelium was examined. The results are shown in Fig. 3. After incubation for $48 \mathrm{hr}$, the addition of the lytic enzyme complex and Emulgen 120 reduced MICs from $1 / 4$ to $1 / 128$, and then even after $120 \mathrm{hr}$, the ratios ranged from $1 / 2$ to $1 / 32$.

Figure 4 shows the relationship between mycelial growth and the absorbance at $260 \mathrm{~nm}$ 


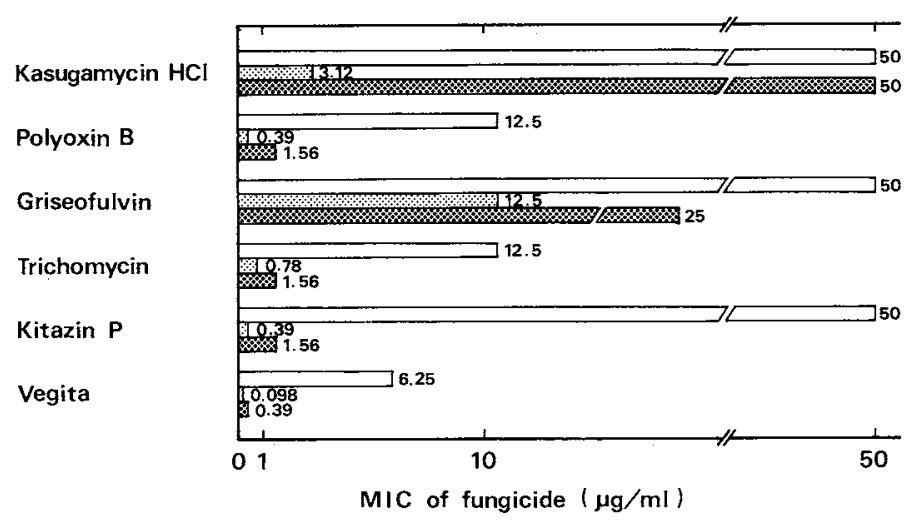

FIG. 3. Decrease in MICs of Fungicides in the Presence of the Lytic Enzyme Complex and Emulgen 120 for P. oryzae.

Emulgen 120 was used at the final concentration of $0.0025 \%$. Other experimental details are given under

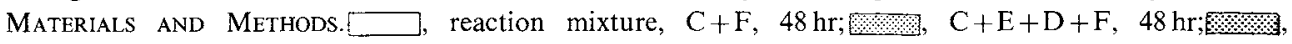
$\mathrm{C}+\mathrm{E}+\mathrm{D}+\mathrm{F}, 120 \mathrm{hr}$.

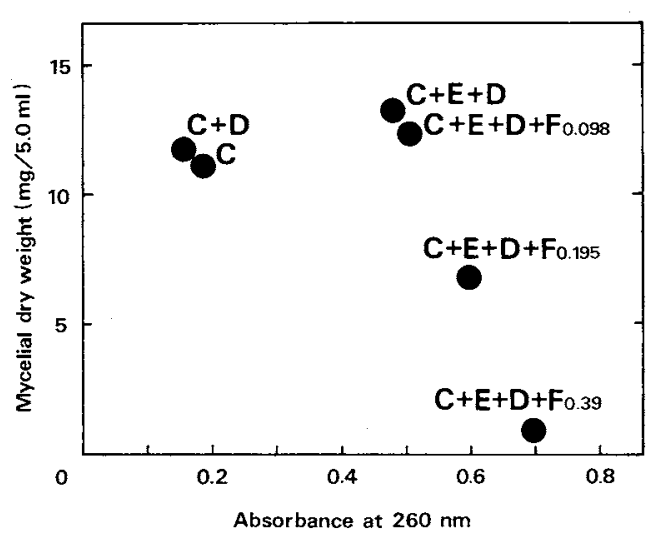

FIG. 4. Relationship between Mycelium Damage and Growth Inhibition.

The test organism was $P$. oryzae. The reaction mixtures were incubated at $28^{\circ} \mathrm{C}$ for $48 \mathrm{hr}$, and then O.D. at $260 \mathrm{~nm}$ of the culture fluid and mycelial dry weight $(\mathrm{mg} / 5 \mathrm{ml})$ were measured. $C$, the basal medium; $\mathrm{E}$, the lytic enzyme complex of B. circulans WL 12 (for details see the text); D, detergent, Emulgen 120 , at the final concentration of $0.0025 \% ; F$, fungicide, Polyoxin B. The subscript numbers indicate the final concentrations $(\mu \mathrm{g} / \mathrm{ml})$.

of the growth medium, to show the extent of mycelial damage. The addition of Emulgen 120 alone hardly caused the leakage of nucleic acid from the mycelia, but the lytic enzyme complex in the presence of the detergent increased the absorbance at $260 \mathrm{~nm}$. When the concentration of a fungicide was increased from 0.098 to $0.39 \mu \mathrm{g} / \mathrm{ml}$, the mycelial dry weight decreased remarkably, while the change in absorbance at $260 \mathrm{~nm}$ was only slight.

Effects of the lytic enzymes and Emulgen 120. on the inhibitory actions of fungicides on the growth of other phytopathogenic fungi

Remarkable decreases in MICs of Polyoxin $\mathrm{B}$, Kitazin $\mathrm{P}$ and Vegita against $P$. oryzae occurred with the combined use of the lytic enzyme complex and Emulgen 120. Additional 4 strains of phytopathogenic fungi were tested in the same manner. As shown in Table II, MICs of Polyoxin B for $B$. cinerea and $C$. lagenarium showed significant decreases. These fungi are susceptible to this fungicide. On the other hand, MICs of Kitazin P, to which these fungi are resistant, also showed marked decreases.

G. cingulata and $A$. kikuchiana are resistant to both Polyoxin B and Kitazin P. MICs of these fungicides for these two strains did not show decreases with the combined use of the lytic enzyme complex and Emulgen 120. The further addition of Novozym 234 or the crude enzyme from Streptomyces species ${ }^{7}$ caused a reduction in MICs, as shown in Table II. Presumably, enzymes such as mannanase degraded the surface components of these fungi, thus allowing the access of glucanase mole- 
Table II. Effects of Lytic Enzymes and Emulgen 120 on Inhibitory Actions of Polyoxin B and Kitazin P on the Growing Mycelia of Phytopathogenic Fungi

The detergent, Emulgen 120, was used at the final concentration of $0.0025 \%$. The lytic enzyme complex was prepared from a culture of $B$. circulans WL 12 . In the case of Novotym 234 as a lytic enzyme, the results are indicated in parentheses.

\begin{tabular}{|c|c|c|c|c|c|c|c|c|}
\hline \multirow{3}{*}{ Organisms } & \multicolumn{4}{|c|}{ MIC of Polyoxin B $(\mu \mathrm{g} / \mathrm{ml})$} & \multicolumn{4}{|c|}{ MIC of Kitazin P $(\mu \mathrm{g} / \mathrm{ml})$} \\
\hline & \multirow{2}{*}{$\begin{array}{l}C+F \\
48 \mathrm{hr}\end{array}$} & \multirow{2}{*}{$\begin{array}{c}C+D+F \\
48 \mathrm{hr}\end{array}$} & \multicolumn{2}{|c|}{$\mathrm{C}+\mathrm{E}+\mathrm{D}+\mathrm{F}$} & \multirow{2}{*}{$\begin{array}{l}C+F \\
48 \mathrm{hr}\end{array}$} & \multirow{2}{*}{$\begin{array}{c}\mathrm{C}+\mathrm{D}+\mathrm{F} \\
48 \mathrm{hr}\end{array}$} & \multicolumn{2}{|c|}{$\mathrm{C}+\mathrm{E}+\mathrm{D}+\mathrm{F}$} \\
\hline & & & $48 \mathrm{hr}$ & $120 \mathrm{hr}$ & & & $48 \mathrm{hr}$ & $120 \mathrm{hr}$ \\
\hline Botrytis cinerea & 12.5 & 12.5 & 0.2 & 0.2 & 500 & 100 & 25 & 100 \\
\hline $\begin{array}{l}\text { Colletotrichum } \\
\text { lagenarium }\end{array}$ & 25 & 12.5 & 0.78 & 1.56 & 500 & 100 & 12.5 & 25 \\
\hline $\begin{array}{l}\text { Alternaria } \\
\quad \text { kikuchiana } \mathrm{Y}-33\end{array}$ & 500 & 500 & $500(50)$ & $500(100)$ & 500 & 500 & $100(50)$ & $500(100)$ \\
\hline $\begin{array}{l}\text { Glomerella } \\
\quad \text { cingulata G 4-1-4 }\end{array}$ & 500 & 500 & $100(12.5)$ & $500(50)$ & 500 & 500 & $500(50)$ & $500(100)$ \\
\hline
\end{tabular}
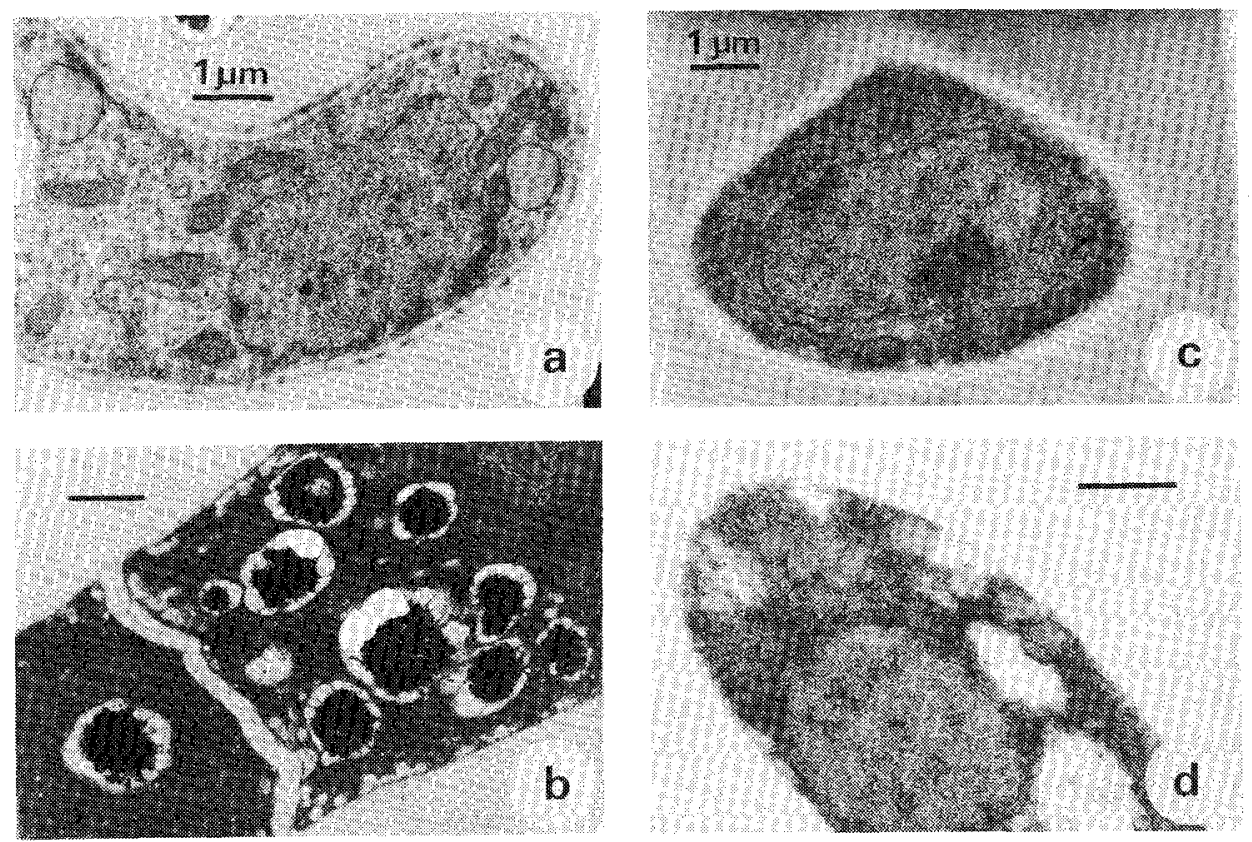

FIG. 5. Electron Micrographs of the Ultrastructures of $P$. oryzae and $G$. cingulata, after Treatment with Emulgen 120.

All the photographs were taken with mycelia after incubation for $48 \mathrm{hr}$. Emulgen 120 were used at the final concentration of $0.01 \%$.

a: A normal hypha of $P$. oryzae without Emulgen 120.

b: A hypha of $P$. oryzae in a reaction mixture containing Emulgen 120 . The cytoplasm has become electrondense. Dense body visicles ${ }^{8}$ are visible.

c: A normal hypha of $G$. cingulata without Emulgen 120 .

$\mathrm{d}$ : A hypha of $G$. cingulata in a reaction mixture containing Emulgen 120 without observable ultrastructural changes. 
cules.

Effect of Emulgen 120 on the ultrastructures of mycelia of $P$. oryzae and $G$. cingulata

Emulgen 120 caused the reduction of MICs of fungicides together with the lytic enzyme complex. In order to demonstrate the effects of Emulgen 120 on the tested fungi, electron microscopic observation was performed. At the concentration of Emulgen $120(0.0025 \%)$, no apparent ultrastructural change was observed for $P$. oryzae or $G$. cingulata cells. However, with a higher concentration of the detergent, $0.01 \%$ (4-fold that used in MIC experiments), obvious ultrastructural changes, especially in $P$. oryzae cells, occurred, as shown in Fig. 5. As described in the previous paper, ${ }^{3)}$ the outermost layer of about $1 \mu \mathrm{m}$ in thickness could be observed in the normal mycelium of $G$. cingulata, although this layer was not observed in P. oryzae cells. This might be the reason why $P$. oryzae is more susceptible to the detergent than $G$. cingulata. This outermost layer might serve as a barrier preventing permeation of the detergent.

\section{DISCUSSION}

The combined use of the lytic enzyme complex of $B$. circulans WL 12 and an appropriate non-ionic detergent was found to effectively reduce MICs of some fungicides for $P$. oryzae (Fig. 3). It has been reported that Polyoxin B and Kitazin $\mathrm{P}$ inhibit chitin biosynthesis. ${ }^{9 \sim 14)}$ The inhibitory effect of the latter on the biosynthesis of phosphatidyl choline has also pointed out. ${ }^{15)}$ Trichomycin binds to sterols in the plasma membrane. ${ }^{16)}$ Vegita is a $\mathrm{SH}-$ enzyme inhibitor. ${ }^{17)}$ These facts indicate that the three fungicides other than Vegita mainly act on the cell surface layers. It has been reported that non-ionic detergents facilitate the permeation of antimicrobial compounds ${ }^{18 \sim 20)}$ and enhance the lytic enzyme activities. ${ }^{21,22)}$ The above facts support our results.

In contrast with $P$. oryzae, however, $G$. cingulata and $A$. kikuchiana required ad- ditional enzymes, mannanase and/or some kind of proteases, for similar effects (Table II). These enzymes appeared to remove the outermost layer of these fungi.

The mechanism of this synergistic action of a fungicide, a lytic enzyme and a non-ionic detergent can be explained on the basis of our results (including unpublished data) as follows: Alteration of the outer surface of fungi through the action of the detergent might facilitate the access of glucanase molecules inside the cell wall, as a result of which the fungicide can permeate into cells more readily.

The combined use of detergents such as Emulgen 120 and lytic enzymes will provide a new screening method for fungicides which influence the biosynthesis-system for cell surface layers of fungi.

Acknowledgments. The authors wish to thank the late Dr. E. Yoshinaga, Kumiai Chemical Industry Co., Ltd., for providing the test microorganisms and the fungicides. The authors also would like to express their thanks to Dr. S. Takahashi, Hokko Chemical Industry Co., Ltd., Dr. S. Ezumi, Kaken Chemical Co., Ltd., Fujisawa Yakuhin Kogyo Co., Ltd. and Nippon Kayaku Co., Ltd. for the generous supplies of fungicides. In addition, their thanks are due to Dr. K. Hattori, Kao Co., Ltd., for providing the sample detergents. This research was supported in part by a Grant-in-Aid for Scientific Research from the Ministry of Education, Science and Culture of Japan.

\section{REFERENCES}

1) H. Tanaka, N. Ogasawara, T. Nakajima and K. Tamari, J. Gen. Appl. Microbiol., 16, 39 (1970).

2) M. C. Allwood, Microbios, 7, 209 (1973).

3) R. Watanabe, T. Hoshino and N. Ogasawara, Agric. Biol. Chem., 50, 325 (1986).

4) H. Tanaka and H. J. Phaff, J. Bacteriol., 89, 1570 (1965).

5) H. Tanaka, N. Ogasawara and S. Kamimiya, Agric. Biol. Chem., 45, 1541 (1981).

6) Y. Kobayashi, H. Tanaka and N. Ogasawara, Agric. Biol. Chem., 38, 959 (1974).

7) R. Watanabe and N. Ogasawara, Abstracts of Papers, the Annual Meeting of the Agricultural Chemical Society of Japan, Kyoto, April, 1981, p. 564.

8) S. N. Grove and C. E. Bracker, "An Atlas of Fungal Ultrastructure," ed. by A. Beckett, I. B. Heath and D. J. McLaughlin, Longman Ltd., London, 1974, p. 221. 
9) M. Hori, K. Kakiki, S. Suzuki and T. Misato, Agric. Biol. Chem., 35, 1280 (1971).

10) S. Sasaki, N. Ota, J. Eguchi, Y. Furukawa, T. Akasiba, T. Tsuchiyama and S. Suzuki, Ann. Phylopath. Soc. Japan, 34, 272 (1968).

11) J. Eguchi, S. Sasaki, N. Ota, T. Akashiba, T. Tsuchiyama and S. Suzuki, Ann. Phytopath. Soc. Japan, 34, 280 (1968).

12) M. Hori, K. Kakiki and T. Misato, Agric. Biol. Chem., 38, 691 (1974).

13) K. Kakiki, T. Maeda, H. Abe and T. Misato, Nippon Nōgeikagaku Kaishi, 43, 37 (1969).

14) T. Maeda, H. Abe, K. Kakiki and T. Misato, Agric. Biol. Chem., 34, 700 (1970).

15) O. Kodama, H. Yamada and T. Akatsuka, Agric. Biol. Chem., 43, 1719 (1979).

16) "Antibiotics," Vol. II, ed. by U. Sumiki, Tokyo
Daigaku Shuppankai, Tokyo, 1961, p. 1034; "Antibiotics," Supplement I, ed. by U. Sumiki, Tokyo Daigaku Shuppankai, Tokyo, 1970, p. 1371.

17) J. R. Corbett, K. Wright and A. C. Baillie, "The Biochemical Mode of Action of Pesticides," Academic Press Inc., London and New York, 1984, p. 301

18) M. R. W. Brown and R. M. E. Richards, J. Pharm. Pharmacol., 16, 51 (1964).

19) M. R. W. Brown and B. E. Winsly, J. Gen. Microbiol., 68, 367 (1971).

20) H. Yamaguchi, Y. Kanda and K. Iwata, Japan. J. Med. Mycol., 15, 18 (1974).

21) F. R. Bernath and W. R. Vieth, Biotechnol. Bioeng., 14, 737 (1972).

22) M. Arai and S. Murao, Agric. Biol. Chem., 42, 1461 (1978). 